УДК 342.9

DOI https://doi.org/10.32849/2663-5313/2020.9.22

\author{
Максим Калатур, \\ докт. юрид. наук, \\ головний науковий співробітник \\ Науково-дослідного інституту публічного права
}

\title{
ОСОБЛИВОСТІ ДІЯЛЬНОСТІ ТА РОЗВИТКУ ДЕРЖАВНОЇ ФІСКАЛЬНОЇ СЛУЖБИ УКРАЇНИ
}

У статті сформульовані основні завданнями Державної фіскальної служби України, а саме: реалізація державної податкової політики та політики у сфері державної митної справи, державної політики у сфері боротьби з правопорушеннями під час застосування податкового, митного законодавства; здійснення в межах повноважень, передбачених законом, контролю за надходженням до бюджетів та державних иільових фондів податків і зборів, митних та інших платежів; здійснення державної політики у сфері контролю за виробництвом та обігом спирту, алкогольних напоїв і тютюнових виробів, державної політики з адміністрування єдиного внеску; боротьба з правопорушеннями під час застосування законодавства з питань сплати єдиного внеску, здійснення державної політики у сфері контролю за своєчасністю здійснення розрахунків в іноземній валюті в установлений законом строк, дотриманням порядку проведення готівкових розрахунків за товари (послуги), а також за наявністю ліцензій на провадження видів господарської діяльності, що підлягають ліщензуванню відповідно до закону, торгових патентів. З'ясовано, що Законом України «Про внесення змін до Податкового кодексу України щодо покращення інвестиційного клімату в Україні» технічно виключено розділ Податкового кодексу про податкову мілічію, що позбавило останню повноважень, яка, незважаючи на ие, продовжувала функиіонувати. Наголошується на недосконалості сучасно20 адміністративно-правового регулювання організаиї та функиіонування слідчих органів у структурі Державної фіскальної служби України, яку має бути позбавлено невластивої ій правоохоронної функиії. 3 метою упорядкування кількості правоохоронних органів, що уповноважені розслідувати економічні злочини у сфері публічних фінансів та взаємодіяти з иих питань із бізнесом, аргументовано дочільність прийняття Закону Украйни «Про Начіональне бюро фінансової безпеки України» із чітким унормуванням правового статусу, основ співпращі такого суб'єкта з державними органами, підприємствами, установами та організаціями, компетентними органами інших держав і міжнародними організачіями, юридичними та фізичними особами.

Ключові слова: юридична особа, службова особа, адміністративні послуги, державна політика.

Актуальність теми. Відповідно до положень Кримінального процесуального кодексу України, одним з органів досудового розслідування (органів, що здійснюють дізнання і досудове слідство) є слідчі підрозділи органів, що здійснюють контроль за додержанням податкового законодавства. Проте в Кримінальному процесуальному кодексі України нині немає жодної вказівки, які саме це органи. Чіткої відповіді на це питання не можна знайти й у Податковому кодексі України, у якому хоча й міститься розділ, присвячений функціонуванню податкової міліції, проте змінами до Кримінального процесуального кодексу та власне податкового законодавства у відповідних перехідних положеннях його планувалося загалом виключити, не узгодивши належним чином при цьому адміністративно-правову базу регулювання організації та функціонування слідчих органів, що здійснюють контроль за додержанням податкового законодавства.

Стан дослідження. Окремі аспекти регулювання діяльності слідчих органів, що здійснюють контроль за додержанням податкового законодавства, висвітлювали О. А. Банчук, О. В. Баулін, Р. Г. Ботвінов, В. М. Галунько, Л. М. Дудник, О. С. Задорожний, А.А.Козіна, В.П.Кононець, В. В.Лисенко, A. О. Ляш, О. А. Марущак, А. В. Самодін, Г. І. Сисоєнко, В. В. Тропін, Г. Г. Філоненко, Г. П. Цимбал та інші правознавці.

Проте, незважаючи на існуючий науковий доробок у даному напрямі, наявні дослідження лише фрагментарно торкаються адміністративно-правового регулювання організації та функціонування слідчих органів, що здійснюють контроль за додержанням податкового законодавства. 
Мета статті - розкрити основні завдання Державної фіскальної служби України, запропонувати шляхи вдосконалення адміністративно-правового регулювання організації та функціонування слідчих органів у структурі Державної фіскальної служби України.

Виклад основного матеріалу. Варто підкреслити, що за даними звіту Державної фіскальної служби (Звіту про роботу органів досудового розслідування за 12 місяців 2018 року), до суду було спрямовано з обвинувальним актом 1158 кримінальних проваджень. Усього у звітному періоді було закінчено 2510 кримінальних проваджень, розпочато - 5020 (станом на 01.01.2019р.) [1]

Водночас слушною вважаємо думку О. А. Банчука, з точки зору якого Кримінальний процесуальний кодекс визначає, що податкові злочини уповноважені розслідувати слідчі «органів, що здійснюють контроль за додержанням податкового законодавства», і в цих же органах можуть створюватися оперативні підрозділи на підставі ст. 41 Кодексу. Усі повноваження органів розслідування та правила розслідування визначені виключно в цьому Кодексі, і в ньому ж відсутня будь-яка згадка про податкову міліцію чи фіскальну службу [2].

3 цього приводу справедливо зазначає також В. Веремко, наголошуючи на тому, що поспіхом прийнятим Законом від 21.12.2016 р. № 1797-VIII «Про внесення змін до Податкового кодексу України щодо покращення інвестиційного клімату в Україні» було «випадково» виключено розділ Податкового Кодексу про податкову міліцію, що позбавило останню повноважень. Утім, у Державній фіскальній службі «заплющують очі» на помилку й працюють так, ніби нічого не сталося. У свою чергу апарат парламенту також не поспішає прибирати скасований розділ із тексту Кодексу, пояснюючи це «внутрішніми неузгодженостями в тексті закону» та «відсутністю повноважень виправляти технічні помилки та неузгодженості в тексті опублікованих законів» [3].

Разом із тим, на думку О. Данилюка, без ліквідації податкової міліції та створення Служби фінансових розслідувань неможливо провести реформу Державної фіскальної служби. I, хоча тї діяльність наразі не передбачена законом (податкова міліція вже понад рік існує поза законом ), податкова міліція є частиною Державної фіскальної служби України, продовжує працювати та фінансуватися 3 державного бюджету, незважаючи на те, що ще в березні 2017-го урядом було запропоновано проект закону про створення Служби фінансових розслідувань [4].
Законопроектом передбачається створення Бюро фінансових розслідувань як центрального органу виконавчої влади, діяльність якого спрямовується та координується Кабінетом Міністрів України через Міністра фінансів України. Бюро фінансових розслідувань складається з центрального апарату та 7 територіальних управлінь, зареєстрованих як юридичні особи публічного права.

Так, з метою розділення сервісної та правоохоронної функцій податкової служби, передбачається ліквідація податкової міліції, оптимізація структури та чисельності органів, які ведуть боротьбу зі злочинами у сфері фінансів, усунення дублювання іх функцій та створення Бюро фінансових розслідувань - центрального органу виконавчої влади, який реалізує державну політику 3 питань запобігання, виявлення, припинення, розслідування та розкриття кримінальних правопорушень у сфері господарської діяльності, які прямо чи опосередковано заподіюють шкоду публічному інтересу у сфері фінансів.

Запропонована модель боротьби з економічними злочинами стане більш ефективною, зменшить податковий тиск на платників податків, що підтверджується такими аргументами:

1) Існування спеціалізованого органу для боротьби з якимось одним явищем (наприклад, податковими злочинами), за законами функціонування бюрократичних систем, призводить до того, що сам такий орган певною мірою консервує і виступає запорукою існування того явища (податкових злочинів), з яким він покликаний боротися: адже повна перемога над цим явищем означає, як наслідок, ліквідацію самого органу. Навіть значне зменшення відповідного явища має призводити до значного скорочення штатної чисельності органу. А як система такий орган у цьому не зацікавлений.

2) Економічні злочини за своєю природою різноманітні, їхній характер яких досить динамічно змінюеться і доповнюється новими способами здійснення правопорушень. Порушення податкового законодавства становить тільки частину економічної злочинності. Такі види, як отримання монопольних надприбутків, порушення правил конкуренції, шахрайство, кіберзлочинність, порушення споживчих норм і стандартів, фальсифікація бухгалтерської звітності, однаковою мірою важко віднести до традиційної компетенції як міністерства внутрішніх справ, так і міністерства фінансів або іншої урядової структури.

3) Дедалі більша частина економічних злочинів скоюється проти приватних або 
публічних корпорацій, фінансових установ їхніми власними співробітниками, клієнтами або партнерами. Викриття більшості таких злочинів здійснюється власними службами безпеки корпорацій і фінансових установ, і тільки після цього інформація передається до правоохоронних органів. Нав'язування бізнесу правоохоронного захисту з боку держави у таких випадках може бути контрпродуктивним для розвитку економіки [5].

3 Наказу Генеральної прокуратури України, Міністерства внутрішніх справ України, Служби безпеки України, Міністерства фінансів України, Національного антикорупційного бюро України від 24.10.2017 р № 298/875/593/866/200-О «Про затвердження Інструкції зі складання звітності про роботу слідчих» (у т. ч. Форми № 1-СЛ «Про роботу слідчих органів, що здійснюють контроль за додержанням податкового законодавства») випливає, що слідчі підрозділи органів, що здійснюють контроль за додержанням податкового законодавства, включають у себе:

1) Головне слідче управління фінансових розслідувань Державної фіскальної служби України;

2) Слідче управління кримінальних розслідувань Головного слідчого управління фінансових розслідувань Державної фіскальної служби України, слідче управління Офісу великих платників податків;

3) слідчі підрозділи органів, що здійснюють контроль за додержанням податкового законодавства у місті Києві, областях, Офісі великих платників податків;

4) слідчі підрозділи органів, що здійснюють контроль за додержанням податкового законодавства, міського та районного рівнів [6].

Разом із тим, згідно із суперечливою ст. 350 (350.1.2) Податкового кодексу України, податкова міліція відповідно до покладених на неї завдань проводить також і досудове розслідування в межах наданої законом компетенції. Завданнями податкової міліції є розслідування та провадження у справах про адміністративні правопорушення у сфері оподаткування та бюджетній сфері (ст. 348.2) [7].

Тобто нині органи досудового розслідування у сфері контролю за додержанням податкового законодавства входять до складу Державної фіскальної служби України.

Варто зауважити, що Державна фіскальна служба України $є$ центральним органом виконавчої влади, діяльність якого спрямовується і координується Кабінетом Міністрів України через Міністра фінансів і який реалізує державну податкову політику, державну політику у сфері державної митної справи, державну політику 3 адміністрування єдиного внеску на загальнообов'язкове державне соціальне страхування, державну політику у сфері боротьби з правопорушеннями під час застосування податкового, митного законодавства, а також законодавства 3 питань сплати єдиного внеску [8], в тому числі провадить досудове розслідування згідно зі встановленою законодавчо підслідністю.

3 п.п. 3-4 Постанови Кабінету Міністрів України від 21.05.2014 р. № 236 «Про Державну фіскальну службу України» випливають і основні завдання діяльності слідчих підрозділів органів, що здійснюють контроль за додержанням податкового законодавства. Загальними завданнями Державної фіскальної служби України є:

1) реалізація державної податкової політики та політики у сфері державної митної справи, державної політики у сфері боротьби 3 правопорушеннями під час застосування податкового, митного законодавства;

2) здійснення в межах повноважень, передбачених законом, контролю за надходженням до бюджетів та державних цільових фондів податків і зборів, митних та інших платежів;

3) здійснення державної політики у сфері контролю за виробництвом та обігом спирту, алкогольних напоїв і тютюнових виробів, державної політики з адміністрування єдиного внеску;

4) боротьба з правопорушеннями під час застосування законодавства 3 питань сплати єдиного внеску, державної політики у сфері контролю за своєчасністю здійснення розрахунків в іноземній валюті в установлений законом строк, дотриманням порядку проведення готівкових розрахунків за товари (послуги), а також за наявністю ліцензій на провадження видів господарської діяльності, що підлягають ліцензуванню відповідно до закону, торгових патентів.

Відповідно, даний орган провадить згідно із законом оперативно-розшукову діяльність, досудове розслідування, а також вживає заходів до відшкодування завданих державі збитків, здійснює розшук осіб, які переховуються від слідства та суду за кримінальні правопорушення у сфері оподаткування, митній та бюджетній сферах; здійснює міжнародне співробітництво, забезпечує виконання зобов'язань, узятих за міжнародними договорами України, з питань, що належать до ії компетенції, у тому числі шляхом надання взаємної адміністративної допомоги у запобіганні, виявленні та розслідуванні порушень законодавства на підставі міжнародних угод [8] 
Також, слід зауважити, що підслідність органів досудового розслідування закріплена в ст. 216 Кримінального процесуального кодексу України, відповідно до якої слідчі органів, що здійснюють контроль за додержанням податкового законодавства, здійснюють досудове розслідування злочинів, передбачених статтями $204,205,205^{1}, 212,212^{1}, 216$, $218^{1}, 219$ Кримінального кодексу України [9].

Тобто йдеться про такі злочини, як:

1) незаконне виготовлення, зберігання, збут або транспортування з метою збуту підакцизних товарів (спирту етилового, спиртових дистилятів, алкогольних напоїв, пива, тютюнових виробів, тютюну, промислових замінників тютюну, пального або інших підакцизних товарів) (ст. 204 Кримінального кодексу України);

2) фіктивне підприємництво - створення або придбання суб'єктів підприємницької діяльності (юридичних осіб) $з$ метою прикриття незаконної діяльності або здійснення видів діяльності, щодо яких є заборона (ст. 205);

3) підроблення документів, які подаються для проведення державної реєстрації юридичної особи та фізичних осіб-підприємців: внесення в документи завідомо неправдивих відомостей, а також умисне подання для проведення такої реєстрації документів, які містять завідомо неправдиві відомості (ст. 205 ${ }^{1}$ );

4) ухилення від сплати податків, зборів (обов'язкових платежів) - умисне ухилення від сплати податків, зборів (обов'язкових платежів), що входять у систему оподаткування, введених у встановленому законом порядку, вчинене службовою особою підприємства, установи, організації, незалежно від форми власності, або особою, що займається підприємницькою діяльністю без створення юридичної особи, чи будь-якою іншою особою, яка зобов'язана їх сплачувати, якщо ці діяння призвели до фактичного ненадходження до бюджетів чи державних цільових фондів коштів у значних розмірах (ст. 212);

5) ухилення від сплати єдиного внеску на загальнообов'язкове державне соціальне страхування та страхових внесків на загальнообов'язкове державне пенсійне страхування - умисне ухилення від сплати єдиного внеску на загальнообов'язкове державне соціальне страхування чи страхових внесків на загальнообов'язкове державне пенсійне страхування, вчинене службовою особою підприємства, установи, організації, незалежно від форми власності, або особою, яка здійснює підприємницьку діяльність без створення юридичної особи, чи будь-якою іншою особою, яка зобов'язана його сплачувати, якщо таке діяння призвело до фактичного ненад- ходження до фондів загальнообов'язкового державного соціального страхування коштів у значних розмірах (ст. $212^{1}$ );

6) незаконне виготовлення, підроблення, використання або збут незаконно виготовлених, одержаних чи підроблених контрольних марок для маркування упаковок примірників аудіовізуальних творів, фонограм, відеограм, комп'ютерних програм, баз даних чи голографічних захисних елементів (ст. 216);

7) доведення банку до неплатоспроможності - умисне, з корисливих мотивів, іншої особистої заінтересованості або в інтересах третіх осіб вчинення пов'язаною з банком особою будь-яких дій, що призвели до віднесення банку до категорії неплатоспроможних, якщо це завдало великої матеріальної шкоди державі або кредитору (ст. 218 ${ }^{1}$;

8) доведення до банкрутства - умисне, 3 корисливих мотивів, іншої особистої заінтересованості або в інтересах третіх осіб вчинення громадянином - засновником (учасником) або службовою особою суб'єкта господарської діяльності дій, що призвели до стійкої фінансової неспроможності суб'єкта господарської діяльності, якщо це завдало великої матеріальної шкоди державі чи кредитору (ст. 219) [9].

Крім того, якщо під час розслідування зазначених злочинів будуть встановлені злочини, передбачені статтями 192, 199, 200 , 222, 222 ${ }^{1}, 358,366$ Кримінального кодексу України [9], вчинені особою, щодо якої здійснюється досудове розслідування, або іншою особою, якщо вони пов'язані зі злочинами, вчиненими особою, щодо якої здійснюється досудове розслідування, вони розслідуються слідчими органів, що здійснюють контроль за додержанням податкового законодавства [10].

\section{Висновки}

Отже, в статті визначено, що нині підгрунтя адміністративно-правового регулювання організації та функціонування слідчих органів, що здійснюють контроль за додержанням податкового законодавства, становлять такі основні нормативно-правові акти, шляхом застосування яких нині воно реалізується: Конституція України; Кримінальний процесуальний кодекс України, Кримінальний кодекс України, Податковий кодекс України; Постанова Кабінету Міністрів України «Про Державну фіскальну службу України»; Наказ Генеральної прокуратури України, Міністерства внутрішніх справ України, Служби безпеки України, Міністерства фінансів України, Національного антикорупційного бюро Українивід 24.10.2017 р.№ 298/875/593/866/200-О «Про затвердження Інструкції зі складання звітності про роботу слідчих» тощо.

З'ясовано, що Законом України «Про внесення змін до Податкового кодексу України 
щодо покращення інвестиційного клімату в Україні» технічно виключено розділ Податкового кодексу про податкову міліцію, що позбавило останню повноважень, яка, незважаючи на це, продовжувала функціонувати.

Наголошується на недосконалості сучасного адміністративно-правового регулювання організації та функціонування слідчих органів у структурі Державної фіскальної служби України, яку має бути позбавлено невластивої їй правоохоронної функції. 3 метою упорядкування кількості правоохоронних органів, що уповноважені розслідувати економічні злочини у сфері публічних фінансів та взаємодіяти з цих питань із бізнесом, аргументовано доцільність прийняття Закону України «Про Національне бюро фінансової безпеки України» із чітким унормуванням правового статусу, основ співпраці такого суб'єкта з державними органами, підприємствами, установами та організаціями, компетентними органами інших держав і міжнародними організаціями, юридичними та фізичними особами.

\section{Список використаних джерел:}

1. Звіт про роботу органів досудового розслідування, що здійснюють контроль за додержанням податкового законодавства за 12 місяців 2017 року. Державна фіскальна служба України : сайт. URL: http://sfs.gov.ua/diyalnist-/pokaznikiroboti/dosudove-slidstvo/ (дата звернення: 02.08.2020).

2. Банчук О. А. Створення СФР: потрібен не закон, а політична воля. Реанімаційний пакет реформ : сайт. URL: https://rpr.org.ua/ news/oleksandr-banchuk-stvorennya-sfr-potribenne-zakon-a-politychna-volya/ (дата звернення: 02.08.2020).
3. Веремко В. Через технічні неузгодженості «вартові податків» залишилися без повноважень, і суди із цим згодні. Закон $i$ бізнес. 2017. № 8 (1306). URL: http://zib.com.ua/ua/ 127742-podatkova_miliciya_bez_povnovazhen poki_zakonodavci_namagayu.html (дата звернення: 02.08̄.2020)

4. Мінфін : Податкова міліція вже більше року існує поза законом. 5. Перший - украйнський-інформаиійний:сайт.URL:https://www.5.ua/ polityka/minfin-podatkova-militsiia-vzhe-ponadrik-isnuie-poza-zakonom-165557.html. (дата звернення: 02.08.2020).

5. Про Бюро фінансових розслідувань : Проект Закону України від 30.08.2019 № 1208. URL:https://w1.c1.rada.gov.ua/pls/zweb2/ webproc4_1?pf3511=66516 (дата звернення: $02.08 .202 \overline{0})$

6. Форма № 1-СЛ «Про роботу слідчих органів, що здійснюють контроль за додержанням податкового законодавства» : додаток 6 до Інструкції зі складання звітності про роботу слідчих (підпункт 1 пункту 2 розділу I) : затв. наказом від 24 жовт. 2017 p. URL: http://zakon5.rada.gov.ua/ laws/show/z1401-17 (дата звернення: 02.08.2020).

7. Податковий кодекс України : прийнятий 2 груд. 2010 р. № 2755-VI. Відомості Верховної Ради Украӥни. 2011. № 13-14, № 15-16, № 17. CT. 112.

8. Про Державну фіскальну службу України : Постанова Кабінету Міністрів України від 21 трав. 2014 р. № 236. URL: http://zakon2.rada. gov.ua/laws/show/236-2014-\%D0\%BF (дата 3вернення: 02.08.2020)

9. Кримінальний кодекс України : прийнятий 05 квіт. 2001 р. № 2341-III. Відомості Верховної Ради Украйни. 2001. № 25-26. Ст. 131.

10. Кримінальний процесуальний кодекс : прийнятий 13 квіт. 2012 р. № 4651-VI. Відомості Верховної Ради Украйни. 2013. № 9-10, № 11-12, № 13. Ст. 88 .

Maksym Kalatur. Features of the activities and development of the State Fiscal Service of Ukraine

The article outlines the main tasks of the State Fiscal Service of Ukraine, namely: implementation of the state tax policy and policy in the field of state customs, state policy in the sphere of combating offenses during the application of tax and customs legislation; exercise within the powers provided for by law the control over the receipt of taxes and duties, customs and other payments into the budgets and state trust funds; implementation of state policy in the sphere of control over production and circulation of alcohol, alcoholic beverages and tobacco, state policy on administration of a single contribution; fight against offenses during the application of the legislation on the payment of a single payment, public policy in the field of control over the timely execution of payments in foreign currency within the statutory period, compliance with the procedure of cash payments for goods (services), as well as the availability of licenses for the management of types of economic activities that are licensed under the law, trade patents. It is found that the Law of Ukraine "On Amendments to the Tax Code of Ukraine on Improving the Investment Climate in Ukraine" technically excluded the section of the Tax Code on Tax Police, which deprived the latter of his powers, which nevertheless continued to operate. The imperfection of the modern administrative and legal regulation of the organization and functioning of the investigative bodies in the structure of the State Fiscal Service of Ukraine is noted, which should be deprived of its non-peculiar law enforcement function. In order to streamline the number of law enforcement agencies empowered to investigate economic crimes in the public finance sphere and to interact with these issues with business, it is reasonable to adopt the Law of Ukraine "On the National Bureau of Financial Security of Ukraine" with a clear normalization of the legal status, the basis of cooperation of such entity public authorities, enterprises, institutions and organizations, competent authorities of other states and international organizations, legal entities and individuals.

Key words: legal entity, official, administrative services, public policy. 